\title{
The Effectiveness of Problem-Solving Therapy for Primary Care Patients' Depressive and/or Anxiety Disorders: A Systematic Review and Meta-Analysis
}

\author{
Anao Zhang, MSW, LCSW, Sunyoung Park, MA, John E. Sullivan, MSW, \\ and Shijie Jing, $P b D$
}

Background: There is increasing demand for managing depressive and/or anxiety disorders among primary care patients. Problem-solving therapy (PST) is a brief evidence- and strength-based psychotherapy that has received increasing support for its effectiveness in managing depression and anxiety among primary care patients.

Methods: We conducted a systematic review and meta-analysis of clinical trials examining PST for patients with depression and/or anxiety in primary care as identified by searches for published literature across 6 databases and manual searching. A weighted average of treatment effect size estimates per study was used for meta-analysis and moderator analysis.

Results: From an initial pool of 153 primary studies, 11 studies (with 2072 participants) met inclusion criteria for synthesis. PST reported an overall significant treatment effect for primary care depression and/or anxiety $(d=0.673 ; P<.001)$. Participants' age and sex moderated treatment effects. Physician-involved PST in primary care, despite a significantly smaller treatment effect size than mental health provider only PST, reported an overall statistically significant effect $(d=0.35 ; P=.029)$.

Conclusions: Results from the study supported PST's effectiveness for primary care depression and/or anxiety. Our preliminary results also indicated that physician-involved PST offers meaningful improvements for primary care patients' depression and/or anxiety. ( $\mathrm{J}$ Am Board Fam Med 2018;31: 139-150.)

Keywords: Anxiety Disorders, Depressive Disorder, Mental Health, Primary Health Care, Problem Solving, Psychotherapy

Depressive and anxiety disorders are the 2 leading global causes of all nonfatal burden of disease ${ }^{1}$ and the most prevalent mental disorders in the US primary care system. ${ }^{2-4}$ The proportion of primary

This article was externally peer reviewed.

Submitted 5 July 2017; revised 14 September 2017; accepted 27 September 2017.

From the Steve Hicks School of Social Work, University of Texas at Austin, Austin, TX (AZ, JES); Quantitative Methods Program, College of Education, The University of Texas at Austin, Austin, TX (SP); School of Social Development, East China University of Political Science and Law, Shanghai, China (SJ).

Funding: none.

Conflict of interest: none declared.

Ethics Review: This is a systematic review and meta-analysis based on de-identified aggregate study data. No human participants or animals were involved in this study. No ethics review was required.

Corresponding author: Anao Zhang, MSW, LCSW, The University of Texas at Austin, 1925 San Jacinto Blvd., Austin, TX, 78712 (E-mail: zhanganao@utexas.edu). care patients with a probable depressive and/or anxiety disorder ranges from $33 \%$ to $80 \%{ }^{2,5,6}$; primary care patients also have alarmingly high levels of co-/multi-morbidity of depressive, anxiety, and physical disorders. ${ }^{7}$ Depression and anxiety among primary care patients contribute to: poor compliance with medical advice and treatment ${ }^{8}$; deficits in patient-provider communication ${ }^{9}$; reduced patient engagement in healthy behaviors ${ }^{10}$; and decreased physical wellbeing. ${ }^{11,12}$ Given the high prevalence of primary care depression and anxiety, and their detrimental effects on the qualities of primary care treatments and patients' wellbeing, it is important to identify effective interventions suitable to address primary care depression and anxiety.

Primary care patients with depression and/or anxiety are often referred out to specialty mental health care. ${ }^{13,14}$ However, outcomes from these 
referrals are usually poor due to patients' poor adherence and their resistance to mental health treatment ${ }^{15,16}$. Therefore, it is critical to identify effective mental health interventions that can be delivered in primary care for patients' depression and/or anxiety. ${ }^{17,18}$ During the past decade, a plethora of clinical trials have investigated different mental health interventions for depression and anxiety delivered in primary care. One of the most promising interventions that has received increasing support for managing depression and anxiety in primary care is Problem-Solving Therapy (PST).

\section{PST}

Holding that difficulties with problem solving make people more susceptible to depression, PST is a nonpharmacological, competence-based intervention that involves a step-by-step approach to constructive problem solving. ${ }^{19,20}$ Developed from cognitive-behavioral-therapy, PST is a short-term psychotherapy approach delivered individually or in group settings. The generic PST manual ${ }^{19}$ contains 14 training modules that guides PST providers working with patients from establishing a therapeutic relationship to identifying and understanding patientprioritized problems; from building problem-solving skills to eventually solving the problems. Focused on patient problems in the here-and-now, a typical PST treatment course ranges from 7 to 14 sessions and can be delivered by various health care professionals such as physicians, clinical social workers or nurse practitioners. Because the generic PST manual outlines the treatment formula in detail, providers may deliver PST after receiving 1 month of training. For example, 1 feasibility study on training residents in PST found that residents can provide fidelious PST after 7 weeks' training and reach moderate to high competence after 3 years of practicing PST. ${ }^{21}$ PST also has a self-help manual available to clients when needed.

PST is a well-established, evidence-based intervention for depression in specialty mental health care and is receiving greater recognition for its effectiveness in treating depression and anxiety in primary care. Systematic and meta-analytic reviews of PST for depression consistently reported moderate to large treatment effects, ranging from $d=$ 0.4 to $d=1.15 .^{22-24}$ Several clinical trials indicated PST's clinical effectiveness in alleviating anxiety as well. ${ }^{25,26}$ Most importantly, PST has been adapted for primary care settings (PST-PC) and can be delivered by a variety of health care providers with fewer number of sessions and shorter session length. These unique features make PST(-PC) an ideal psychotherapy for depressive and/or anxiety disorders in primary care.

Previous reviews of PST focused on its effectiveness for depression care, but with little attention to PST's effect on anxiety or comorbid depression anxiety. In addition, to our knowledge, no previous reviews of PST have focused on managing depressive and/or anxiety disorders in primary care. Although research demonstrates that PST has a strong evidence base for treating depression and/or anxiety in specialty mental health care settings, more research is needed to determine whether PST remains effective for treating depressive and/or anxiety disorders when delivered in primary care. To address this gap, we conducted a systematic review and meta-analysis on the effectiveness of PST for treating depressive and/or anxiety disorders with primary care patients.

\section{Methods}

\section{Search Strategies}

This review included searches in 6 electronic databases (Academic Search Complete, CINAHL, Medline, PsychINFO, PUBMED, and the Cochrane Library/Database) and 3 professional Web sites (Academy of Cognitive Therapy, IMPACT, Anxiety and Depression Association of America) for primary care depression and anxiety studies published between January 1900 and September 2016. We also E-mailed major authors of PST studies for feedback and input. Search terms of title and/or abstract searches included: ["PST" or "Problem-Solving Therapy" or "Problem Solving Therapy" or "Problem Solving"] AND ["Depression" or "Depressive" or "Anxiety" or "Panic" or "Phobia"] AND ["primarycare" or "primary care" or "PCP" or "Family Medicine" or "Family Doctor"]. We supplemented the procedure described above with a manual search of study references.

\section{Eligibility Criteria}

For inclusion in analyses, a study needed to be 1) a randomized-controlled-trial of 2) PST for 3) primary care patients' 4) depressive and/or anxiety disorders. For studies that examined face-to-face, in-person PST, the intervention must be delivered 
in primary care for inclusion. If studies examined tele-PST (eg, telephone delivery, video conferencing, computer-based), the intervention must be connected to patients' primary care services for a study to be included. For example, when a primary care physician prescribed computer-based PST at home for their patients, the study met inclusion criteria (as it was still considered managing depression "in primary care" in the present review). However, studies would be excluded if a primary care physician referred patients to an external mental health intervention. Finally, studies must document and report sufficient statistical information for calculating effect size for inclusion in the final analysis.

\section{Data Abstraction and Coding}

Two authors (AZ and JES) reviewed an initial pool of 153 studies and agreed to remove 65 studies based on title and 68 studies based on abstract, resulting in 20 studies for full-text review. To develop the final list, we excluded 6 studies after closer review of full-text and consultation with a third reviewer who is an established PST researcher. Lastly, we excluded 2 studies due to 1 ) a study with a design that blurred the effect of PST with other treatments and 2) unsuccessful contact with a study author to request data needed for calculating effect size. We used a final sample of 11 studies for meta-analysis. The PRISMA chart is presented in Figure 1.

\section{Statistical Analysis}

This study conducted meta-analysis with the following procedures: 1) calculated a weighted average of effect size estimates per study for depression and anxiety separately (to ensure independence) ${ }^{27}$; 2) synthesized an overall treatment effect estimate using fixed- or random-effects model based on a heterogeneity statistic (Q-statistic) ${ }^{28}$; and 3) per-

Figure 1. Preferred Reporting Items for Systematic Reviews and Meta-Analyses (PRISMA) chart of literature search for Problem-solving therapy (PST) studies for treating primary care patients' depression and/or anxiety.

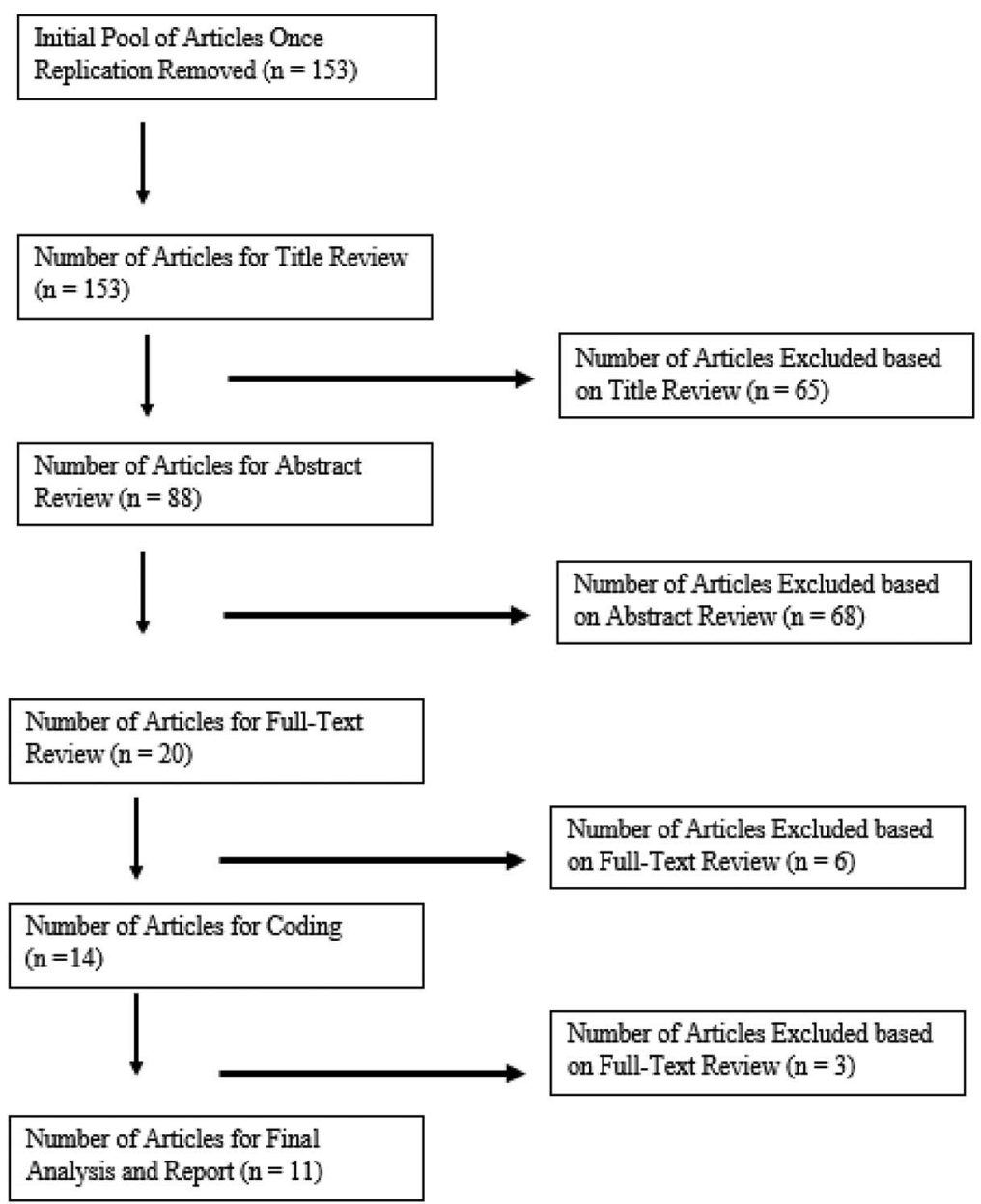


Table 1. Study Characteristics for Problem-Solving Therapy as Intervention for Treating Depression and/or Anxiety Among Primary Care Patients $(n=11)$

\begin{tabular}{|c|c|c|c|c|c|c|c|}
\hline Author & Sample* & Demographics $^{\dagger}$ & Control $^{\ddagger}$ & $\begin{array}{l}\text { Provider and } \\
\text { PCP's role in } \\
\text { PST (if } \\
\text { applicable) }\end{array}$ & $\begin{array}{l}\text { PST/PST-PC } \\
\text { Dosage }\end{array}$ & $\begin{array}{c}\text { Diagnostic or } \\
\text { Symptom } \\
\text { Severity } \\
\text { Criteria }\end{array}$ & $\begin{array}{l}\text { Depression and/or } \\
\text { Outcome Measures }\end{array}$ \\
\hline $\begin{array}{l}\text { Barrett et al. } \\
\quad(2001)\end{array}$ & $\begin{array}{l}\mathrm{T}=80 \\
\mathrm{C} 1=80 \\
\mathrm{C} 2=81^{\$}\end{array}$ & $\begin{array}{l}44.1 \text { year old } \\
\text { (SD NR), } \\
36.1 \% \text { male, } \\
90 \% \text { white. }\end{array}$ & $\begin{array}{l}\text { MED } \\
\text { Placebo }\end{array}$ & $\begin{array}{l}\text { Ph.D-level } \\
\text { psychologists. } \\
\text { PCP no } \\
\quad \text { involvement }\end{array}$ & $\begin{array}{l}6 \text { PST-PC sessions, } \\
\text { lasting about } 1 \\
\text { hour for the first } \\
\text { visit and } 30 \\
\text { minutes for } \\
\text { subsequent visits. }\end{array}$ & $\begin{array}{l}\text { DSM-III-R, } \\
\text { HDRS, } \\
\text { PRIME- } \\
\text { MD }\end{array}$ & $\begin{array}{l}\text { HSCL-D-20 } \\
\text { HDRS }\end{array}$ \\
\hline $\begin{array}{l}\text { Chibanda et al. } \\
\text { (2014) }\end{array}$ & $\begin{array}{l}\mathrm{T}=30 \\
\mathrm{C}=28\end{array}$ & $\begin{array}{l}24.5 \text { years old } \\
\quad(\mathrm{SD}=4.9) \\
\% \text { male NR } \\
\text { Race NR }\end{array}$ & MED & $\begin{array}{l}\text { Trained Peer } \\
\text { Counselor. } \\
\text { PCP no } \\
\text { involvement }\end{array}$ & $\begin{array}{l}12 \text { sessions }(60 \text { mins } \\
\text { per session) } \\
\text { group PST } \\
\text { session which } \\
\text { were modeled } \\
\text { after a 7-step } \\
\text { management plan } \\
\text { for depression } \\
\text { published earlier } \\
\text { (Abbas et al., } \\
\text { 1994) }\end{array}$ & DSM-IV & EPDS \\
\hline $\begin{array}{l}\text { Katon et al. } \\
\quad(2004)\end{array}$ & $\begin{array}{l}\mathrm{T}=164 \\
\mathrm{C}=165\end{array}$ & $\begin{array}{l}58.3 \text { years old } \\
(\mathrm{SD}=12), \\
35 \% \text { male, } \\
75.4 \% \text { white. }\end{array}$ & TAU & $\begin{array}{l}\text { Registered nurses } \\
\text { in collaboration } \\
\text { with the PCP }\end{array}$ & $\begin{array}{l}\text { Medication OR } \\
\text { PST-PC, there is } \\
\text { a stepped-care } \\
\text { algorithm }^{\text {II }}\end{array}$ & $\begin{array}{l}\text { PHQ-9 } \\
\text { Did not } \\
\text { require } \\
\text { diagnostic } \\
\text { criteria }\end{array}$ & SCL-90 depression \\
\hline $\begin{array}{l}\text { Lam et al. } \\
\qquad(2009)\end{array}$ & $\begin{array}{l}\mathrm{T}=149 \\
\mathrm{C}=150\end{array}$ & $\begin{array}{l}71.8 \text { years old } \\
\quad(\mathrm{SD}=7.0) \\
43.14 \% \text { male, } \\
\text { Race NR }\end{array}$ & $\mathrm{A} C^{\|}$ & $\begin{array}{l}\text { Primary care } \\
\text { physicians }\end{array}$ & $\begin{array}{l}3 \text { sessions of } \\
\text { modified PST- } \\
\text { PC (Mynors- } \\
\text { Wallis et al., } \\
\text { 2000), first } \\
\text { session } 30 \text { to } 45 \\
\text { minutes. session } 2 \\
\text { \& } 320 \text { to } 30 \\
\text { minutes. }\end{array}$ & HADS score & $\begin{array}{l}\text { HADS (AS), } \\
\text { HADS (DS) } \\
\text { SF-36 mental }\end{array}$ \\
\hline $\begin{array}{l}\text { Lynch et al. } \\
\text { (2004) }\end{array}$ & $\begin{array}{l}\mathrm{T}=9 \\
\mathrm{C} 1=9 \\
\mathrm{C} 2=13\end{array}$ & $\begin{array}{l}38.5 \text { years old } \\
\quad(\mathrm{SD}= \\
13.7), \\
17 \% \text { male } \\
\text { Race NR }\end{array}$ & $\begin{array}{l}\mathrm{AC}^{* *} \\
\text { TAU }\end{array}$ & $\begin{array}{l}\text { Registered nurses. } \\
\text { PCP referral, no } \\
\text { other } \\
\text { involvement }\end{array}$ & $\begin{array}{l}6 \text { sessions of } \\
\text { telephone-based } \\
\text { PST (adopted } \\
\text { Nezu, Nezu, \& } \\
\text { Perri, 1989) }\end{array}$ & $\begin{array}{l}\text { PRIME-MD } \\
\text { HRSD }\end{array}$ & $\begin{array}{l}\text { PRIME-MD, } \\
\text { HRSD } \\
\text { BDI, DHP-D-A }\end{array}$ \\
\hline $\begin{array}{l}\text { McCusker et al. } \\
\text { (2008). }\end{array}$ & $\begin{array}{l}\mathrm{T}=36 \\
\mathrm{C}=32\end{array}$ & $\begin{array}{l}73.3 \text { years old } \\
\quad(\mathrm{SD}= \\
8.6), \\
33.8 \% \text { male } \\
\text { Race NR }\end{array}$ & TAU & $\begin{array}{l}\text { Depression care } \\
\text { practitioner } \\
\text { supervised by } \\
\text { (and in } \\
\text { collaboration } \\
\text { with) PCP }\end{array}$ & $\begin{array}{l}4 \text { sessions PST } \\
\text { intervention }(60 \text { - } \\
\text { minute first } \\
\text { session, } 30 \text { mins } \\
\text { for the rest) } \\
\text { developed based } \\
\text { on IMPACT }\end{array}$ & PHQ-2 & $\begin{array}{l}\text { SCL-20, SF-12 } \\
\text { SCID }\end{array}$ \\
\hline $\begin{array}{l}\text { Mynors-Wallis } \\
\text { et al. (2000) }\end{array}$ & $\begin{array}{l}\mathrm{T} 1=80 \\
\mathrm{~T} 2=35 \\
\mathrm{C}=36\end{array}$ & $\begin{array}{l}35 \text { years old } \\
(\mathrm{SD}= \\
\text { NR), } \\
23 \% \text { male, } \\
95 \% \text { white }\end{array}$ & MED & $\begin{array}{l}\text { General } \\
\text { practitioner } \\
\text { Nurse and } \\
\text { General } \\
\text { Practitioner } \\
\text { (PCP) }\end{array}$ & $\begin{array}{l}6 \text { sessions PST-PC, } \\
\text { with first session } \\
1 \mathrm{hr} \text {, others } 30 \\
\text { minutes }\end{array}$ & HDRS score & BDI-I \\
\hline $\begin{array}{l}\text { Oxman et al. } \\
\text { (2008) }\end{array}$ & $\begin{array}{l}\mathrm{T}=72 \\
\mathrm{C}=69\end{array}$ & $\begin{array}{l}55.2 \text { years old } \\
\quad(\mathrm{SD}=16), \\
41.8 \% \text { male, } \\
96.5 \% \text { white }\end{array}$ & TAU & $\begin{array}{l}\text { Masters level } \\
\text { counselor. } \\
\text { PCP referral, no } \\
\text { other } \\
\text { involvement }\end{array}$ & $\begin{array}{l}6 \text { sessions PST-PC, } \\
\text { with first session } \\
1 \mathrm{hr} \text {, others } 30 \\
\text { minutes }\end{array}$ & $\begin{array}{l}\text { DSM-IV, } \\
\text { HAM-D, } \\
\text { PRIME-MD }\end{array}$ & $\begin{array}{l}\text { HAM-D, MADRS } \\
\text { HSCL-D-20 }\end{array}$ \\
\hline $\begin{array}{l}\text { Reynolds et al. } \\
(2014)\end{array}$ & $\begin{array}{l}\mathrm{T}=125 \\
\mathrm{C}=122\end{array}$ & $\begin{array}{l}36.5 \text { years old } \\
(\mathrm{SD}= \\
10.9) \\
28.7 \% \text { male } \\
62.3 \% \text { white }\end{array}$ & TAU & $\begin{array}{l}\text { Social workers } \\
\text { and mental } \\
\text { health nurses } \\
\text { PCP referral, no } \\
\text { other } \\
\text { involvement }\end{array}$ & $\begin{array}{l}6 \text { to } 8 \text { sessions } \\
\text { PST-PC, with } \\
\text { first session } 1 \mathrm{hr} \text {, } \\
\text { the rest } 30 \\
\text { minutes }\end{array}$ & $\begin{array}{l}\text { CES-D, } \\
\text { DSM-IV; } \\
\text { MMSS }\end{array}$ & $\begin{array}{l}\text { BDI, SF-12 } \\
\text { CIRSG, BSI - } \\
\text { Anxiety }\end{array}$ \\
\hline $\begin{array}{l}\text { Schmaling et } \\
\text { al. (2002) }\end{array}$ & $\begin{array}{l}\mathrm{T}=31^{\dagger \dagger} \\
\mathrm{C} 1=31 \\
\mathrm{C} 2=30\end{array}$ & $\begin{array}{l}42.8 \text { years old } \\
(\mathrm{SD}= \\
10.7) \\
39.1 \% \text { male } \\
88.0 \% \text { white }\end{array}$ & $\begin{array}{l}\text { MED } \\
\text { Placebo }\end{array}$ & $\begin{array}{l}\text { Trained therapists } \\
\text { with no further } \\
\text { specification } \\
\text { PCP referral, no } \\
\text { other } \\
\text { involvement }\end{array}$ & $\begin{array}{l}6 \text { sessions PST-PC, } \\
\text { with first session } \\
1 \mathrm{hr} \text {, others } 30 \\
\text { minutes }\end{array}$ & $\begin{array}{l}\text { DSM-III-TR } \\
\text { PRIME-MD, } \\
\text { HRSC }\end{array}$ & $\begin{array}{l}\text { HAM-D (17-item) } \\
\text { HSCL-D (20- } \\
\text { item) }\end{array}$ \\
\hline
\end{tabular}




\begin{tabular}{|c|c|c|c|c|c|c|c|}
\hline Author & Sample* & Demographics $^{\dagger}$ & Control $^{\ddagger}$ & $\begin{array}{l}\text { Provider and } \\
\text { PCP's role in } \\
\text { PST (if } \\
\text { applicable) }\end{array}$ & $\begin{array}{c}\text { PST/PST-PC } \\
\text { Dosage }\end{array}$ & $\begin{array}{c}\text { Diagnostic or } \\
\text { Symptom } \\
\text { Severity } \\
\text { Criteria }\end{array}$ & $\begin{array}{l}\text { Depression and/or } \\
\text { Outcome Measures }\end{array}$ \\
\hline \multirow[t]{2}{*}{$\begin{array}{l}\text { Williams et al. } \\
\qquad(2000)\end{array}$} & \multirow[t]{2}{*}{$\begin{array}{l}\mathrm{T}=138 \\
\mathrm{C} 1=137 \\
\mathrm{C} 2=140\end{array}$} & $\begin{array}{l}71 \text { years old } \\
(\mathrm{SD}= \\
7.0), \\
58.5 \% \text { male, }\end{array}$ & $\begin{array}{l}\text { MED } \\
\text { Placebo }\end{array}$ & $\begin{array}{l}\text { PhD } \\
\text { Psychologists, } \\
\text { Social workers, } \\
\text { and Psychology } \\
\text { Counselors }\end{array}$ & \multirow[t]{2}{*}{$\begin{array}{l}6 \text { sessions PST-PC, } \\
\text { with first session } 1 \\
\text { hr, others } 30 \\
\text { minutes }\end{array}$} & \multirow[t]{2}{*}{$\begin{array}{l}\text { DSM-III-R, } \\
\text { HDRS } \\
\text { DSM-IV, } \\
\text { PRIME- } \\
\text { MD }\end{array}$} & \multirow[t]{2}{*}{$\begin{array}{l}\text { HSCL-D-20 } \\
\text { HDRS }\end{array}$} \\
\hline & & $78.2 \%$ white & & $\begin{array}{l}\text { PCP no } \\
\text { involvement }\end{array}$ & & & \\
\hline
\end{tabular}

*Sample size: $\mathrm{T}$, treatment; $\mathrm{T}_{2}$, treatment 2 if applicable; $\mathrm{C}$, control.

${ }^{\dagger}$ Demographic: NR, not reported.

${ }^{\ddagger}$ Control: TAU, treatment as usual, W/NT, waitlist or no treatment; MED, medication; Placebo, placebo medication.

${ }^{\S} \mathrm{C} 1$, medication paroxetine; $\mathrm{C} 2$, Placebo.

IParticipants in the treatment group $(68.7 \%)$ received PST. Therefore, the authors believed the effect of intervention can be attributed to PST. Because sensitivity analysis that excluded this study did not alter the overall treatment effect, we included and presented this study in final analysis.

$\|_{\mathrm{AC}}$, active control (health education video).

**Active control (stress management).

${ }^{+\dagger}$ Specific breakdown of the numbers was not reported in article, thus assigned arbitrarily.

BSI, Brief Symptoms Inventory; CES-D, Center for Epidemiology Scale-Depression; DCS = depression care specialist; DFD; depression-free days; DHP-D-A, Duke Health Profile-Depression-Anxiety; EPDS, 10-item Edinburgh Postnatal Depression Scale; HAM-D, Hamilton Rating Scale for Depression; HADS, Hospital Anxiety and Depression Scale; HDRS, Hamilton Depression Rating Scale; HRSD, Hamilton Rating Scale for Depression; HSCL-D-20, Hopkins Depression self-report scale; MADRS, Montgomery-Åsberg Depression Rating Scale; MED, Medication Management; PCP, Primary Care Physician; PHQ-2, Patient Health Questionnaire, 2-item; PHQ-9, Patient Health Questionnaire, 9-item; PRIME-MD, Primary Care Evaluation of Mental Disorders; RDC, Research Diagnostic Criteria; SCL-20, Hopkins depression symptom checklist; SCL-90 depression, Hopkins Symptom Checklist-90 depression questions; SCID/DSM-IV, Structured Clinical Interview for DSM-IV Axis II Personality Disorders (SCID-II); SF-12, SF-36 Health Survey 12-item version; TAU, Treatment as Usual; CIRSG, Cumulative Illness Rating Scale for Geriatrics.

Abbas M, Broadhead JC, Mbape P, Khumalo-Sakatukwa G. Defeating depression in the developing word: A Zimbabwean model. Br $\mathcal{Z}$ Psychiatry 164(3):293-296.

Mynors-Wallis LM, Gath DH, Day A, Baker F. Randomised controlled trial of problem solving treatment, antidepressant medication, and combined treatment for major depression in primary care. BM7 320:26-30.

Nezu A, Nezu C, Perri M. Problem-solving therapy for depression. New York: Wiley; 1989.

formed univariate meta-regression with a mixedeffects model for moderator analysis. ${ }^{29}$ Although other more advanced statistical approaches allow inclusion of multiple treatment effect size estimates per study for data synthesis, like the Generalized Least Squares method ${ }^{30}$ or the Robust Variance Estimation method ${ }^{31}$, this study employed a typical approach because of the relatively small sample and absence of study information required to conduct more advanced methods. Following procedures outlined by Cooper and colleagues ${ }^{32}$, we conducted all analyses with $\mathrm{R}$ software. ${ }^{33} \mathrm{We}$ chose to conduct analyses in $\mathrm{R}$, rather than software specific to metaanalysis (eg, RevMan), because R allowed for more flexibility in statistical modeling (eg, small sample size correction). ${ }^{34}$ Sensitivity analysis using Robust Variance Estimation did not significantly alter results estimated with the typical approach. And so this study presents results from only the typical approach for purposes of parsimony and clarity.

\section{Publication Bias, Risk of Bias and Quality of Studies}

To detect publication bias, we used a funnel plot of effect size estimates graphed against their standard errors for visual investigation. To evaluate risk of bias, we used the Cochrane Collaboration's tool for assessing risk of bias in randomized trials ${ }^{35}$ and the Quality Assessment of Controlled Intervention Studies to evaluate study quality. ${ }^{36}$

\section{Results \\ Primary Studies}

Eleven PST studies for primary care depression and/or anxiety reported a total sample size of 2072 participants. Participants' age averaged 50.1 and ranged from 24.5 to 71.8 years old. Ten studies reported participants' sex with an average of 35.6\% male participants across all studies. Seven studies (63.6\%) reported participants' racial background with 
most identified as non-Hispanic white (83.6\%). Other racial/ethnic groups were poorly reported for meaningful summary. Five studies used active medication as a comparison, including 3 studies that used both active medication and placebo medication. The rest compared PST with treatment-as-usual while 2 studies used active control group (eg, video education material). Four studies involved physicians in some component of intervention delivery. PCPs provided PST in 2 studies; supervised and collaborated with depression care manager in 1 study, and collaborated with a primary care nurse in another. Ten studies reported an average of 6 PST sessions $(M=6.1)$ ranging from 3 to 12 sessions. All but 1 study $(\mathrm{n}=10)$ used individual PST and 2 studies used tele-health modalities to provide PST. All studies used standardized measures of depression and anxiety. Examples of the most common measures included: PHQ-9, CES-D, HAM-D, and BDI-II. Table 1 presents a detailed description of study characteristics.

\section{Publication Bias, Risk of Bias, and Quality of Studies}

The funnel plot (Figure 2) did not indicate any clear sign of publication bias. Risk of bias (Table 4) indicated an overall acceptable risk across studies included for review with blinding of participants and personnel, blinding of outcome assessment and incomplete outcome data most vulnerable to risk of bias. Quality of study assessment (Table 5) indicated an overall satisfactory study quality with over half of studies $(n=6)$ achieving ratings of "Good" study quality.

\section{Meta-analysis and moderator analysis}

Figure 3 presents a forest plot of treatment effects per study, including depression and anxiety measures. Table 3 presents subgroup analysis of overall treatment effect by moderator and Table 2 presents the results of meta-analysis and moderator analysis. Meta-analysis revealed an overall significant treatment effect of PST for primary care depression and/or anxiety $(d=0.67 ; P<.001)$. Further investigation revealed no significant difference between the mean treatment effect of PST for depression versus anxiety in primary care $(d($ diff. $)=-0.25$; $P=.317$ ) while subgroup analysis revealed the overall treatment effect for anxiety was not significant $(d=0.35 ; P=.226)$. Age was found to be a significant moderator $\left(\beta_{1}=0.02 ; P=.012\right)$ for

Figure 2. Funnel Plot for Publication Bias in Problem-solving therapy (PST) Studies for Treating Primary Care Patients' Depression an/or Anxiety.

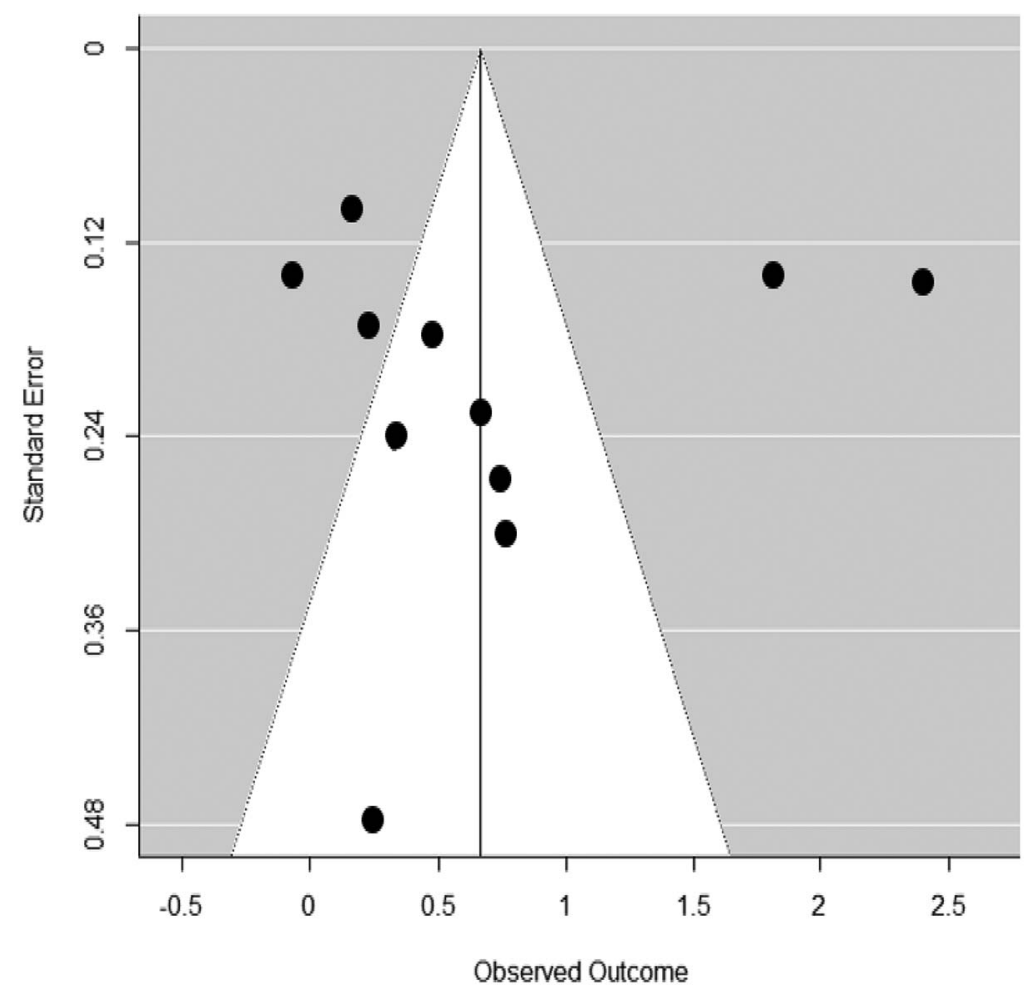


treatment outcomes, indicating that for each unit increase in participants' age, the overall treatment effect for primary are depression and/or anxiety are expected to increase by 0.02 (standard deviations). Neither participants' ethnic or racial backgrounds nor marital status significantly moderated the overall treatment outcome.

The overall treatment effect was not moderated by any treatment characteristics including: treatment modality (individual vs group PST), delivery methods (face-to-face vs tele-health PST), number of PST sessions and length of individual PST sessions. Subgroup analysis indicated an overall significant treatment effect of in-person PST $(d=0.72$; $P<.001)$ but not of tele-PST $(d=0.53 ; P=.097)$. However, the difference between the 2 was not statistically significant.
PST providers background and primary care physician's involvement significantly moderated the overall treatment effect size. Master's-level providers reported an overall treatment effect $(d=$ $1.57 ; P<.001)$ significantly higher than doctorallevel providers $(d=-1.33 ; P=.007)$. Both physician-involved and nonphysician involved PST reported significant overall treatment effect of PST for depression and/or anxiety in primary care $(d=$ $1.06 ; P<.001$ and $d=0.35 ; P=.029$, respectively). Moderator analysis further revealed that PST without physician involvement reported significantly greater treatment effects compared with physician-involved PST in primary care $(d=$ $-0.71 ; P=.005)$. Results of subgroup and moderator analyses indicated that while the difference (in treatment effect) between physician and nonphysi-

Table 2. PST for Treating Primary Care Patients' Depression and/or Anxiety; Results of Univariate Meta-regression

\begin{tabular}{|c|c|c|c|c|}
\hline Parameter* $^{*}$ & Estimate & $95 \% \mathrm{CI}$ & $\mathrm{t}(d f)$ & $P$ Value \\
\hline Overall Effect $\left(\beta_{0}\right)$ & 0.673 & 0.467 to 0.879 & $z=6.41$ & .000 \\
\hline Depression $\left(\beta_{0}\right)$ & 0.601 & 0.224 to 0.978 & $t(11)=3.12$ & .007 \\
\hline Anxiety $\left(\beta_{1}\right)$ & -0.249 & -1.015 to 0.516 & $t(11)=-0.64$ & .317 \\
\hline $\operatorname{Age}^{\dagger}\left(\beta_{0}\right)$ & 0.696 & 0.477 to 0.915 & $\mathrm{t}(10)=6.23$ & .000 \\
\hline Age $\left(\beta_{1}\right)$ & 0.020 & 0.007 to 0.033 & $t(10)=2.97$ & .012 \\
\hline$\%$ Male $\left(\beta_{0}\right)$ & -1.408 & -2.161 to -0.655 & $t(10)=-3.66$ & .004 \\
\hline$\%$ Male $\left(\beta_{1}\right)$ & 0.053 & 0.035 to 0.071 & $t(10)=5.63$ & .000 \\
\hline$\%$ White $\left(\beta_{0}\right)$ & 0.741 & -0.030 to 1.511 & $\mathrm{t}(7)=1.88$ & .075 \\
\hline$\%$ White $\left(\beta_{1}\right)$ & 0.001 & -0.009 to 0.011 & $t(7)=0.14$ & .381 \\
\hline$\%$ Married $\left(\beta_{0}\right)$ & 0.398 & 0.066 to 0.729 & $t(5)=2.35$ & .041 \\
\hline$\%$ Married $\left(\beta_{1}\right)$ & 0.007 & -0.013 to 0.026 & $t(5)=0.66$ & .296 \\
\hline Individual $\left(\beta_{0}\right)$ & 0.668 & 0.455 to 0.880 & $\mathrm{t}(11)=6.16$ & .000 \\
\hline Group $\left(\beta_{1}\right)$ & 0.092 & -0.769 to 0.954 & $\mathrm{t}(11)=0.21$ & .381 \\
\hline Family $\left(\beta_{2}\right)$ & - & & - & - \\
\hline In-person $\left(\beta_{0}\right)$ & 0.722 & 0.494 to 0.950 & $t(10)=6.22$ & .000 \\
\hline Tele-health $\left(\beta_{1}\right)$ & -0.189 & -0.846 to 0.469 & $\mathrm{t}(10)=-0.56$ & .328 \\
\hline Combined $\left(\beta_{2}\right)$ & - & & - & - \\
\hline Session No. $\left(\beta_{0}\right)$ & 0.465 & -0.213 to 1.142 & $t(11)=1.34$ & .157 \\
\hline Session No. $\left(\beta_{1}\right)$ & 0.035 & -0.074 to 0.144 & $t(11)=0.63$ & .315 \\
\hline Min per session $\left(\beta_{0}\right)$ & -0.005 & -1.443 to 1.433 & $\mathrm{t}(10)=-0.01$ & .389 \\
\hline Min per session $\left(\beta_{1}\right)$ & 0.017 & -0.018 to 0.052 & $\mathrm{t}(10)=0.96$ & .241 \\
\hline Master Level $\left(\beta_{0}\right)$ & 1.569 & 1.181 to 1.957 & $\mathrm{t}(9)=7.92$ & .000 \\
\hline Doctoral Level $\left(\beta_{1}\right)$ & -1.334 & -2.112 to -0.557 & $t(9)=-3.36$ & .007 \\
\hline Multi-Discipline $\left(\beta_{2}\right)$ & -1.280 & -1.757 to -0.802 & $\mathrm{t}(9)=-5.26$ & .000 \\
\hline No Physician $\left(\beta_{0}\right)$ & 1.058 & 0.755 to 1.362 & $\mathrm{t}(11)=6.83$ & .000 \\
\hline Yes Physician $\left(\beta_{1}\right)$ & -0.711 & -1.124 to -0.298 & $\mathrm{t}(11)=-3.38$ & .005 \\
\hline
\end{tabular}

${ }^{*} \beta_{0}$ should be interpreted as an intercept in a regression, that is the overall average (effect size) of the reference group. $\beta_{1}$ should be interpreted as a regression coefficient in a regression, that is the difference (in effect size) between the reference group and the predicting group, noted as $d$ (diff.) in the text for categorical variable (moderator). For cells with no numeric value, it was either because of missing data or not enough variation for a statistical estimate to be calculated.

${ }^{\dagger}$ Participant age was mean-centered.

PST, problem-solving therapy. 
Figure 3. Forest Plot of PST Treatment Effect Size Estimates for Treating Primary Care Patients' Depression and/or Anxiety per Study.

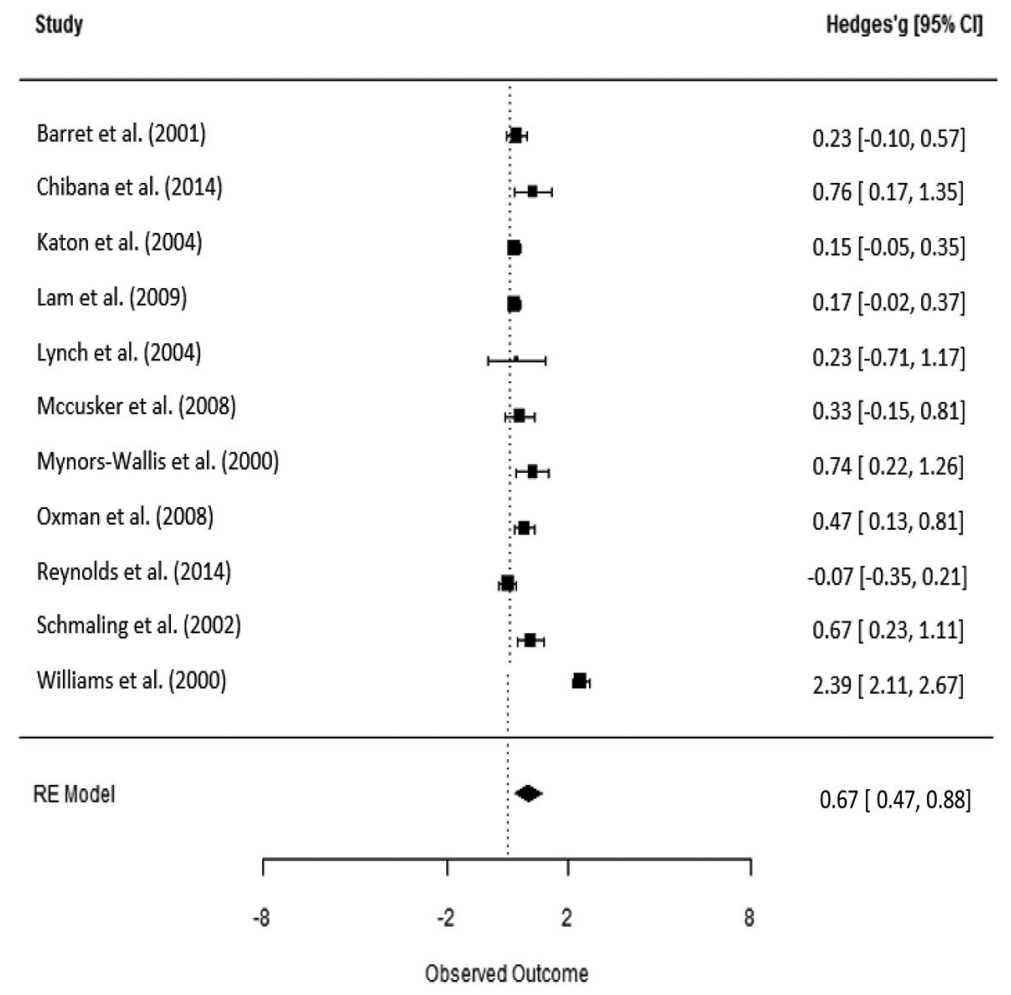

cian involved PST in primary care were statistically significant, physician-involved PST was also statistically significant, thus practically meaningful.

\section{Discussion}

Results of the study demonstrated a statistically significant overall treatment effect in outcomes of depression and/or anxiety for primary care patients receiving PST compared with patients in control groups. The outcome type-depression versus anxiety-failed to moderate treatment effect; only PST for depression reported a significant overall effect size. This could indicate that many studies primarily targeted depression and included anxiety measures as secondary outcomes. For this reason, we expect to find a greater treatment effect for primary care depression. It was unsurprising that treatment characteristics failed to moderate treatment effect size because most primary studies used PST-PC or its modified version; there was insufficient variation between studies (and moderators), yielding insignificant moderating coefficients.

Although delivery method did not moderate treatment effect reported in studies included in this review, significant effect was only reported by studies using face-to-face in-person PST but not by those with tele-PST modalities $(\mathrm{n}=2)$. Although evidence for the effectiveness of tele-PST is established or increasing in a variety of settings ${ }^{37-39}$ most PST studies for primary care patients have used face-to-face, in-person PST. Our study further supported the use of face-to-face in-person PST for treating depression and anxiety among primary care patients. We recognize, however, that current and projected shortages in specialty mental health care provision, felt acutely in subspecialties such as geriatric mental health, necessitate more trials with PST tele-health modalities. ${ }^{40}$

It is salient to note that, while nonphysicianinvolved PST studies reported significantly greater treatment effect than those involving physicians, PCP-involved studies also reported an overall significant effect size. Closer examination indicated that studies with physician-involved PST were either delivered by physicians or other nonmental health professionals (eg, registered nurses or depression care managers). Lack of sufficient PST training might explain the difference in treatment 
Table 3. Results of Subgroup Analysis of Overall Treatment Effect (by Moderator) of PST for Treating Primary Care Patients' Depression and/or Anxiety

\begin{tabular}{|c|c|c|c|c|}
\hline Parameter & Estimate & $95 \% \mathrm{CI}$ & $\mathrm{t}(d f)$ & $P$ Value \\
\hline Depression & 0.601 & 0.224 to 0.978 & $\mathrm{t}(11)=3.12$ & .007 \\
\hline Anxiety & 0.352 & -0.314 to 1.018 & $\mathrm{t}(16)=1.04$ & .226 \\
\hline Individual & 0.668 & 0.455 to 0.880 & $t(11)=6.16$ & .000 \\
\hline Group & 0.760 & -0.075 to 1.595 & $\mathrm{t}(12)=1.78$ & .085 \\
\hline Family & - & - & - & - \\
\hline In-person & 0.722 & 0.494 to 0.950 & $t(10)=6.22$ & .000 \\
\hline Tele-health & 0.533 & -0.083 to 1.150 & $\mathrm{t}(11)=1.70$ & .097 \\
\hline Combined & - & - & - & - \\
\hline Master level & 1.569 & 1.181 to 1.957 & $\mathrm{t}(9)=7.92$ & .000 \\
\hline Doctoral level & 0.235 & -0.439 to 0.909 & $\mathrm{t}(11)=0.68$ & .304 \\
\hline Multi-discipline & 0.290 & -0.012 to 0.567 & $t(11)=2.04$ & .056 \\
\hline Physician not involved & 1.058 & 0.755 to 1.362 & $\mathrm{t}(11)=6.83$ & .000 \\
\hline Physician involved & 0.347 & 0.068 to 0.627 & $t(12)=2.43$ & .029 \\
\hline
\end{tabular}

For cells with no numeric value, it was either because of missing data or not enough variation for a statistical estimate to be calculated. CI, confidential interval; PST, problem-solving therapy.

effect sizes being statistically significant. Yet, the fact that physician-involved PST studies reported an overall statistically significant effect size for primary care depression and/or anxiety suggested a meaningful treatment effect for clinical practice. When faced with a shortage of mental health pro- fessionals (eg, psychologists, clinical social workers, licensed professional counselors), our findings suggest physician-led or -supervised PST interventions could still improve primary care patients' depression and/or anxiety. Researchers are encouraged to further examine the treatment effect of PST delivered by mental

Table 4. PST for Treating Primary Care Patients' Depression and/or Anxiety; Results of the Cochrane Collaboration's Tool for Assessing Risk of Bias*

\begin{tabular}{|c|c|c|c|c|c|c|c|}
\hline Study/Year & $\begin{array}{c}\text { Random Sequence } \\
\text { Generation }\end{array}$ & $\begin{array}{l}\text { Allocation } \\
\text { Concealment }\end{array}$ & $\begin{array}{l}\text { Blinding of } \\
\text { Participants } \\
\text { and } \\
\text { Personnel }\end{array}$ & $\begin{array}{l}\text { Blinding of } \\
\text { Outcome } \\
\text { Assessment }\end{array}$ & $\begin{array}{l}\text { Incomplete } \\
\text { Outcome } \\
\text { Data }\end{array}$ & $\begin{array}{l}\text { Selective } \\
\text { Reporting }\end{array}$ & $\begin{array}{c}\text { Other Source } \\
\text { of Bias }\end{array}$ \\
\hline Barrett et al. (2001) & + & + & $?$ & $?$ & $?$ & + & + \\
\hline $\begin{array}{l}\text { Chibanda et al. } \\
\text { (2014) }\end{array}$ & + & $?$ & $?$ & $?$ & $?$ & + & $?$ \\
\hline Katon et al. (2004) & + & + & - & + & $?$ & + & - \\
\hline Lam et al. (2009) & + & + & + & $?$ & $?$ & + & + \\
\hline Lynch et al. (2004) & $?$ & $?$ & $?$ & $?$ & $?$ & $?$ & $?$ \\
\hline $\begin{array}{l}\text { McCusker et al. } \\
\text { (2008) }\end{array}$ & + & + & $?$ & $?$ & $?$ & + & + \\
\hline $\begin{array}{l}\text { Mynors-Wallis et al. } \\
(2000)\end{array}$ & - & + & + & $?$ & $?$ & $?$ & $?$ \\
\hline Oxman et al. (2008) & + & $?$ & - & $?$ & $?$ & + & $?$ \\
\hline $\begin{array}{l}\text { Reynolds et al. } \\
\text { (2014) }\end{array}$ & + & + & + & + & + & + & + \\
\hline $\begin{array}{l}\text { Schmaling et al. } \\
\text { (2002) }\end{array}$ & + & $?$ & - & - & $?$ & $?$ & + \\
\hline $\begin{array}{l}\text { Williams et al. } \\
\text { (2000) }\end{array}$ & + & + & $?$ & $?$ & $?$ & $?$ & + \\
\hline Number of "+"s & 9 & 7 & 3 & 2 & 1 & 7 & 6 \\
\hline
\end{tabular}

$*$ * $"=$ criteria were met in primary studies, thus no bias present; "?" = unclear whether or not criteria met from reading of primary studies; and "-" = criteria were not met in primary studies, thus bias present. 
Table 5. Quality Assessment of Controlled PST Intervention Studies for Primary Care Patients' Depression and/or Anxiety $(n=11)$

\begin{tabular}{lcc}
\hline Study/Year & Good & Fair \\
\hline Barrett et al. $(2001)^{41}$ & $\checkmark$ & \\
Chibanda et al. $(2014)^{42}$ & & \\
Katon et al. $(2004)^{43}$ & $\checkmark$ & \\
Lam et al. $(2009)^{44}$ & $\checkmark$ & $\checkmark$ \\
Lynch et al. $(2004)^{45}$ & & $\checkmark$ \\
Mccusker et al. $(2008)^{46}$ & & $\checkmark$ \\
Mynors-Wallis et al. & & \\
$\quad(2000)^{47}$ & $\checkmark$ & $\checkmark$ \\
Oxman et al. $(2008)^{48}$ & & \\
Reynolds et al. $(2014)^{49}$ & $\checkmark$ & \\
Schmaling et al. $(2002)^{50}$ & & \\
Williams et al. $(2000)^{51}$ & & \\
\hline
\end{tabular}

health professionals in collaboration with primary care physicians.

\section{Limitation}

This study has several weaknesses that are inherent to meta-analyses. There is no way to assure we included all studies despite adopting a comprehensive search and coding strategy (ie, file drawer problem). Second, while all studies in this metaanalysis seemed to have satisfactory methodological rigor, it is possible that internal biases within some studies may influence results. This study takes a quantitative meta-analysis approach which inherently neglects other study designs and methodologies that also provide valuable information about the effectiveness, feasibility, and acceptability of PST for treating primary care patients with depression. To ensure independence of data, this study used a weighted average of effect size estimates per study in synthesizing an overall treatment effect and conducting moderator analysis. While sensitivity analysis did not reveal significant differences from the reported results, we will not know for sure how our choice of statistical method might affect the results.

\footnotetext{
The authors are grateful to Dr. Namkee Choi, Professor and the Louis and Ann Wolens Centennial Chair in Gerontology at the University of Texas at Austin Steve Hicks School of Social Work, for her mentorship and insightful comments during preparation of the manuscript.
}

To see this article online, please go to: http://jabfm.org/content/ 31/1/139.full.

\section{References}

1. Whiteford HA, Degenhardt L, Rehm J, et al. Global burden of disease attributable to mental and substance use disorders: Findings from the Global Burden of Disease Study 2010. Lancet 2013;382:157586.

2. Kroenke K, Spitzer RL, Williams JB, Monahan PO, Löwe B. Anxiety disorders in primary care: Prevalence, impairment, comorbidity, and detection. Ann Intern Med 2007;146:317-25.

3. Luxama C. Collaborative care for depression. Am Fam Physician 2014;89:524-5.

4. Prins MA, Verhaak PF, Hilbink-Smolders M, et al. Outcomes for depression and anxiety in primary care and details of treatment: A naturalistic longitudinal study. BMC Psychiatry 2011;11:180.

5. Mitchell AJ, Vaze A, Rao S. Clinical diagnosis of depression in primary care: A meta-analysis. Lancet 2009;374:609-19.

6. Young AS, Klap R, Sherbourne CD, Wells KB. The quality of care for depressive and anxiety disorders in the United States. Arch Gen Psychiatry 2001;58: 55-61.

7. Löwe B, Spitzer RL, Williams JB, Mussell M, Schellberg D, Kroenke K. Depression, anxiety and somatization in primary care: syndrome overlap and functional impairment. Gen Hosp Psychiatry 2008; 30:191-9.

8. Clarke DM, Currie KC. Depression, anxiety and their relationship with chronic diseases: A review of the epidemiology, risk and treatment evidence. Med J Aust 2009;190(7 Suppl):S54-S60.

9. Schenker Y, Stewart A, Na B, Whooley MA. Depressive symptoms and perceived doctor-patient communication in the heart and soul study. J Gen Intern Med 2009;24:550-6.

10. Luger TM, Suls J, Vander Weg MW. How robust is the association between smoking and depression in 
adults? A meta-analysis using linear mixed-effects models. Addict Behav 2014;39:1418-29.

11. Salovey P, Rothman AJ, Detweiler JB, Steward WT. Emotional states and physical health. Am Psychol 2000;55:110-21.

12. Thoits PA. Stress and health: Major findings and policy implications. J Health Soc Behav 2010;51(1 suppl):S41-S53.

13. Williams JW. Primary care physicians' approach to depressive disorders: Effects of physician specialty and practice structure. Arch Fam Med 1999;8: 58-67.

14. Hunkeler EM, Katon W, Tang L, et al. Long term outcomes from the IMPACT randomised trial for depressed elderly patients in primary care. BMJ 2006;332:259-63.

15. Wang PS, Lane M, Olfson M, Pincus HA, Wells KB, Kessler RC. Twelve-month use of mental health services in the United States: results from the $\mathrm{Na}$ tional Comorbidity Survey Replication. Arch Gen Psychiatry 2005;62:629-40.

16. Thielke S, Vannoy S, Unützer J. Integrating mental health and primary care. Prim Care 2007;34: 571-92, vii.

17. Bower P, Richards D, Lovell K. The clinical and cost-effectiveness of self-help treatments for anxiety and depressive disorders in primary care: A systematic review. Br J Gen Pract 2001;51:838-45.

18. Gilbody S, Whitty P, Grimshaw J, Thomas R. Educational and organizational interventions to improve the management of depression in primary care: A systematic review. JAMA 2003;289:3145-51.

19. Nezu AM, Maguth Nezu C, D’Zurilla TJ. Problemsolving therapy: A treatment manual. New York, NY: Springer; 2013.

20. D'Zurilla TJ, Nezu AM. Problem-solving therapy: A positive approach to clinical intervention. 3rd ed. New York, NY: Springer; 2006.

21. Hegel MT, Dietrich AJ, Seville JL, Jordan CB. Training residents in problem-solving treatment of depression: A pilot feasibility and impact study. Fam Med 2004;36:204-8.

22. Bell AC, D'Zurilla TJ. Problem-solving therapy for depression: A meta-analysis. Clin Psychol Rev 2009; 29:348-53.

23. Cuijpers P, van Straten A, Warmerdam L. Problem solving therapies for depression: A meta-analysis. Eur Psychiatry 2007;22:9-15.

24. Kirkham JG, Choi N, Seitz DP. Meta-analysis of problem solving therapy for the treatment of major depressive disorder in older adults. Int J Geriatr Psychiatry 2016;31:526-35.

25. Kleiboer A, Donker T, Seekles W, van Straten A, Riper H, Cuijpers P. A randomized controlled trial on the role of support in Internet-based problem solving therapy for depression and anxiety. Behav Res Ther 2015;72:63-71.
26. Mikami K, Jorge RE, Moser DJ, et al. Prevention of post-stroke generalized anxiety disorder, using escitalopram or problem-solving therapy. J Neuropsychiatry Clin Neurosci 2014;26:323-8.

27. Ellis PD. The essential guide to effect sizes: An introduction to statistical power, meta-analysis and the interpretation of research results. Power 2009; (852): $16-24$.

28. Higgins JP, Thompson SG. Quantifying heterogeneity in a meta-analysis. Stat Med 2002;21:1539-58.

29. Raudenbush SW. Analzying effect sizes: Randomeffects models. Handb Res Synth meta-analysis 2009;295-315.

30. Gleser LJ, Olkin I. Stochastically dependent effect sizes. In: Cooper H, Hedges LV, Valentine JC, eds. The handbook of research synthesis and meta-analysis. 2nd ed. New York, NY: Russel Sage Foundation; 2009, 357-76.

31. Hedges LV, Tipton E, Johnson MC. Robust variance estimation in meta-regression with dependent effect size estimates. Res Synth Methods 2010;1: 39-65.

32. Cooper, Harris LV, Valentine, et al. The handbook of research synthesis and meta-analysis. Vol 3. 2009. New York, NY: Russell Sage Foundation.

33. R Development Core Team. R: A language and environment for statistical computing. R Foundation for Statistical Computing, Vienna, Austria. Vienna, Austria: R Foundation for Statistical Computing 2015.

34. Tipton E, Pustejovsky JE. Small-sample adjustments for tests of moderators and model fit using robust variance estimation in meta-regression. Journal of Educational and Behavioral Statistics 2015;40:604634.

35. Higgins JP, Altman DG, Gøtzsche PC, et al. The Cochrane Collaboration's tool for assessing risk of bias in randomised trials. BMJ 2011;343(2):d5928d5928.

36. National Heart, Lung, and Blood Institute. Quality assessment of controlled intervention studies. Systematic evidence reviews and clinical practice guideline. Available from: https://www.nhlbi.nih.gov/ health-pro/guidelines/in-develop/cardiovascularrisk-reduction/tools/rct.

37. Choi NG, Hegel MT, Marti CN, Marinucci ML, Sirrianni L, Bruce ML. Telehealth problem-solving therapy for depressed low-income homebound older adults. Am J Geriatr Psychiatry 2014;22:263-71.

38. Choi NG, Wilson NL, Sirrianni L, Marinucci ML, Hegel MT. Acceptance of home-based telehealth problem-solving therapy for depressed, low-income homebound older adults: Qualitative interviews with the participants and aging-service case managers. Gerontologist 2014;54:704-13.

39. Cartreine JA, Locke SE, Buckey JC, Sandoval L, Hegel MT. Electronic problem-solving treatment: Description and pilot study of an interactive media 
treatment for depression. JMIR Res Protoc 2012;1: e11.

40. Clarke G, Yarborough BJ. Evaluating the promise of health IT to enhance/expand the reach of mental health services. Gen Hosp Psychiatry 2013;35:339-44.

41. Barret JE, Williams JW, Oxman TE, Frank E, et al. Treatment of dysthymia and minor depression in primary care. Journal of Family Practice 2001; 50: 405-412.

42. Chibanda D, Shetty AK, Tshimanga M, Woelk G, Stranix-Chibanda L, Rusakaniko S. Group problemsolving therapy for postnatal depression among HIV-positive and HIV-negative mothers in Zimbabwe. Journal of the International Association of Providers of AIDS Care 2014;13:335-341.

43. Katon WJ, Von Korff M, Lin EH, et al. The pathways study: A randomized trial of collaborative care in patients with diabetes and depression. Arch Gen Psychiatry 2004;1;61:1042-1049.

44. Lam CL, Fong DY, Chin WY, et al. Brief problemsolving treatment in primary care (PST-PC) was not more effective than placebo for elderly patients screened positive of psychological problems. International Journal of Geriatric Psychiatry 2010;25: 968-980.

45. Lynch D, Tamburrino M, Nagel R, Smith MK. Telephone-based treatment for family practice pa- tients with mild depression. Psychological Reports 2004;94:785-792.

46. McCusker J, Cole M, Yaffe M, et al. Project DIRECT: Pilot study of a collaborative intervention for depressed seniors. Canadian Journal of Community Mental Health 2009; 29;27:201-18.

47. Mynors-Wallis LM, Gath DH, Day A, Baker F. Randomised controlled trial of problem solving treatment, antidepressant medication, and combined treatment for major depression in primary care. BMJ 2000;320:26-30.

48. Oxman TE, Hegel MT, Hull JG, Dietrich AJ. Problem-solving treatment and coping styles in primary care for minor depression. Journal of Consulting and Clinical Psychology. 2008;76:933.

49. Reynolds III CF, Thomas SB, Morse JQ, et al. Early intervention to preempt major depression among older black and white adults. Psychiatric Services 2014;65:765-73.

50. Schmaling KB, Dimidjian S, Katon $W$, Sullivan $M$. Response styles among patients with minor depression and dysthymia in primary care. Journal of Abnormal Psychology 2002;111:350.

51. Williams Jr JW, Barrett J, Oxman T, Frank E, Katon W, Sullivan M, Cornell J, Sengupta A. Treatment of dysthymia and minor depression in primary care: A randomized controlled trial in older adults. JAMA 2000;27;284:1519-26. 